\title{
AN INCREASE IN THE NUMBER OF VISITORS TO SWEDISH Museums AND HistoricAL SITES
}

Göran Nylöf

A new report, Kulturbarometern i detalj: Tema Konst, museer och utställningar ('The Barometer of Culture in Detail: Theme Art, Museums and Exhibitions') has recently (Spring 1995) been published by the National Council for Cultural Affairs. Its introductory part presents the Swedish population as visitors to museums, historic and prehistoric sites. Its second part describes the general interest among the population for arts and crafts and the ways in which they are expressed. It is based on interviews conducted in 1993 by the Audience and Program Research Department (now closed) at the Swedish Broadcasting Corporation. The results represent attitudes in all Swedishspeaking people in Sweden between 15 and 79 years of age.

The data make a comparison possible with a study from 1988, almost identical in its methodology, which was carried out as a joint venture by the National Council for Culture and the same Audience Research Department. I shall here particularly deal with the statistics of the first section of the report and the notable differences from the corresponding numbers from the 1988 report. Note that the report does not deal with the number of visits reported from the museums themselves. It mirrors the attitudes revealed through interviews of a representative sample of people. I shall also dwell on the changes in visiting habits affecting the age group 3-14 years, apparent in the data available in Kulturbarometern 1991-93 ('The Barometer of Culture 1991-93') and in Småbarnens kultur- och mediebarometer 1992 ('Small Children's Barometer of Culture and Media 1992').

\section{CHILDREN - A CONSIDERABLE SECTION OF MUSEUM VISITORS}

In the age group 5-6 years more than half of the total number have visited a museum 
200 in the last 12 months. Most of the visits were made together with an adult member of the child's family or with a relative. Every fourth visit was made with groups from nursery schools or day-care centres. When children begin school at the age of seven, four out of five have already visited a museum - most of them several times.

In the early school years even more children get a chance to familiarize themselves with museums. In the age group 714 years close to $60 \%$ have visited a museum in the past 12 months. Of course visits with school groups have an increased importance, but visits with parents are still frequent. Above the age of 14 the interest in museums dwindles rapidly, but it reappears in the age groups with children of their own of pre-school or school age.

The typical adult visitor, male or female, is a well-educated parent between 35 and 45 years old living in Stockholm.

\section{THE TOTAL NUMBER OF VISITORS HAS INCREASED AFTER 1988}

Towards the end of the 1960s the museums experienced an active period. In 1969 40\% of the population over 16 years of age visited a museum. In the 1970 s and 80 s the number of adult visitors decreased. Thus in 1988 only one out of three was a museum visitor. However there was a large presumptive public - people with a latent motivation not strong enough, however, to get them started, or constantly occupied with matters they had to give priority to. Some prospective museum visitors had competing cultural interests which ruled out the museum alternative. After 1988 a considerable rise in the proportion of annual museum visitors in the population has taken place so that even the level of the 1960s has been exceeded.

In 1993 approximately half the Swedish population over 15 years of age had visited a museum in the past 12 months - a considerable increase as in 1988 only a third of the adult population had been to a museum. Good exhibitions attracting the learning motivated part of the population have been the means of raising public attendance especially in the national museums in Stockholm. The typical new visitor is a well-educated woman in her 30 's, without children, living in Stockholm. In the past few years the tendency has been for museum-visiting habits to depend on socio-economic background and for big cities to strengthen their position when it comes to attracting museum visitors. The conscious effort to activate new groups in the population to take an interest in museums has largely resulted in increased attendance by groups which already had well-established visiting habits. The new visitors in no way corresponded to the potential visitors with a latent motivation discussed above.

The number of school children below 15 however is less than in the 1988 statistics nevertheless they are still more numerous than the average for the adult population. The cutting of school-budgets for the purpose of museum visiting and other extramural cultural activities in many municipalities may have caused the reduced numbers. In the 80 s schools and municipalities cooperated to develop cultural programmes for children and young people which is shown statistically in the total rise in numbers of museum visits although the share of adult museum visitors in the population decreased. 


\section{MUSEUM VISITORS ARE TRAVELLERS}

Almost half of museum visitors have visited a museum in Stockholm in the last year which means that a lot of people not resident in the Stockholm area have gone there to see an exhibition or to study a collection. This willingness to travel is also reflected in the fact that every fourth visitor has been to a museum outside their own län ('administrative region'), as many have been to a museum abroad. Among museum visitors living in rural areas with few museums - somewhat surprisingly twice as many visited a museum in Stockholm as went to their own regional museum. Even museums abroad have attracted more visitors in this category than the regional museum. Among museum visitors living in the regional centres (with a museum) approximately the same number have been to a museum in Stockholm as visited the regional museum. The habit of museum visiting is perhaps linked not to an everyday need for cultural activity but to the extraordinary visit to the capital and to the ritual of charter trips. All data point to the fact that museum visitors are geographically mobile and accustomed to travelling. It seems that to many of them a museum becomes interesting only when situated outside their own region.

\section{VISITORS TO DIFFERENT}

\section{CATEGORIES OF MUSEUMS}

Approximately half the visits have been paid to an art museum or to the art department of a "general» museum. Museums of cultural history attract almost as many visitors. Museums of natural history or technology museums attract a third of the total number. This indicates that those types of museums arouse great public interest, although they are more rare than art and cultural history museums. Close to every second visitor has also been to an open air museum; Skansen in Stockholm in fact attracts more visitors than any other museum in the country. But Skansen also has its zoological garden and its amusement park with renowned restaurants to offer. Every fifth visitor has visited at least three of the categories mentioned above.

For all museum types the same visiting pattern holds: people with little formal education (nine years of compulsory school) are not such frequent and habitual visitors as those with higher formal education. The difference however is not as great for cultural history museums as for other types. A particularly conspicuous exception is the 'working-place' museums, where visitors with an academic background are more numerous than 'labourers'.

\section{AN INCREASING INTEREST IN VISITS TO HISTORICAL SITES, LOCAL COLLECTIONS AND EXHIBITIONS}

Almost half the Swedish population had visited a historical site in the past year. A church (not to attend services), a castle or a manor have been visited by a third of the population. Not quite as many have visited prehistoric sites with rune stones, burial mounds or ruins. Slightly more than $20 \%$ of the population have visited other sites from historic times and half of that number have been to old industries and workshops which have become 
202 museums after their proper activities were discontinued.

Historical sites available to the public in fact attract more visitors than museums and exhibitions, and the visitor groups are only partly the same. In both groups however the well-educated are clearly over-represented.

In conclusion: the overall tendency is evident: sites as well as local collections and exhibitions outside museums provoked a greater public response in 1993 than in 1988. The same picture is true of traditional museums of other types - more visitors have found their way to them. In spite of this the over-representation of city-dwellers and university-educated people in the public remains unchanged. The considerable effort made in the 80 s by school authorities to develop cultural habits in the children has been weakened - in any case the proportion of schoolchildren visiting a museum at least once a year has decreased markedly.

Museums in Stockholm and abroad seem more attractive to many adults than the museums within their own region.

Göran Nylöf is a sociologist. He directed the first systematic studies of exhibition visitors in Sweden for'The Swedish Travelling Exhibitions' (Riksutställningar) in the late 1960s. He is now working as an expert for the Research Department of the Swedish National Council for Cultural Affairs.

Adr: Statens Kulturråd, Box 7843,

S-10398 Stockholm. Fax +46-(0)8-6111349. 